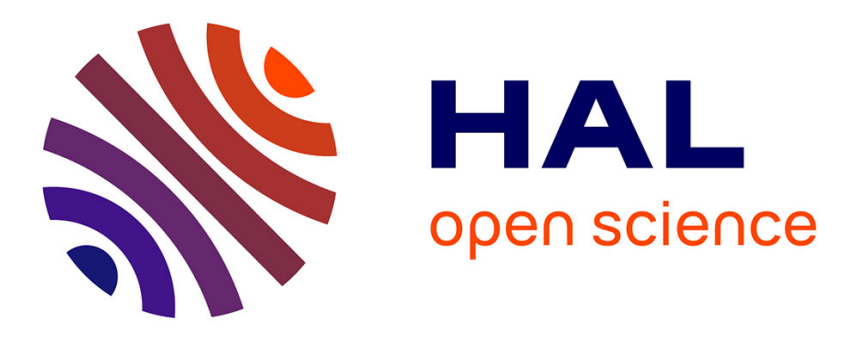

\title{
Susceptibility of polar cod (Boreogadus saida) to a model carcinogen
}

\author{
Adélaïde Lerebours, Svetlana Murzina, You Song, Knut Erik Tollefsen, Maura \\ Benedetti, Francesco Regoli, Jeanette M Rotchell, Jasmine Nahrgang
}

\section{- To cite this version:}

Adélaïde Lerebours, Svetlana Murzina, You Song, Knut Erik Tollefsen, Maura Benedetti, et al.. Susceptibility of polar cod (Boreogadus saida) to a model carcinogen. Marine Environmental Research, 2021, 170, pp.105434. 10.1016/j.marenvres.2021.105434 . hal-03298908

\section{HAL Id: hal-03298908 \\ https://hal.science/hal-03298908}

Submitted on 25 Jul 2021

HAL is a multi-disciplinary open access archive for the deposit and dissemination of scientific research documents, whether they are published or not. The documents may come from teaching and research institutions in France or abroad, or from public or private research centers.
L'archive ouverte pluridisciplinaire HAL, est destinée au dépôt et à la diffusion de documents scientifiques de niveau recherche, publiés ou non, émanant des établissements d'enseignement et de recherche français ou étrangers, des laboratoires publics ou privés. 


\section{Susceptibility of polar cod (Boreogadus saida) to a model carcinogen}

2

3 Adélaïde Lerebours ${ }^{1,2, *}$, ${ }^{3}$ Svetlana Murzina, ${ }^{4}$ You Song, ${ }^{4}$ Knut Erik Tollefsen, ${ }^{5}$ Maura

4 Benedetti, ${ }^{5}$ Francesco Regoli, ${ }^{6}$ Jeanette M. Rotchell and ${ }^{7}$ Jasmine Nahrgang

5

$6{ }^{1}$ School of Biological Sciences, University of Portsmouth, Portsmouth, PO1 2DY, United

7 Kingdom

$8 \quad{ }^{2}$ UMR CNRS LIENSs, Littoral Environnement et Sociétés, Université de La Rochelle, La

9 Rochelle, 17 000, France

$10{ }^{3}$ Institute of Biology of the Karelian Research Centre of the Russian Academy of Sciences

11 (IB KarRC RAS) 185910 Petrozavodsk, Russia

$12{ }^{4}$ Norwegian Institute for Water Research (NIVA), Section of Ecotoxicology and Risk

13 Assessment, Gaustadalléen 21, N-0349 Oslo, Norway

145 Department of Life and Environmental Sciences, Polytechnic University of Marche,

15 Ancona, 60131, Italy

$16{ }^{6}$ Department of Biological and Marine Sciences, University of Hull, Cottingham Road, Hull,

17 HU6 7RX, United Kingdom

$18{ }^{7}$ Department of Arctic and Marine Biology, Faculty of Biosciences, Fisheries and Economics

19 UiT The Arctic University of Norway, 9037 Troms $\varnothing$, Norway

21 Keywords: Carcinogenesis, polar cod, benzo(a)pyrene, cancer genes, DNA repair genes

22

23 * Corresponding author: Adélaïde Lerebours, phone number: +33 (0) 5465076 23, email:

24 adelaide.1erebours@univ-lr.fr 


\section{Abstract}

27 Studies that aim to characterise the susceptibility of the ecologically relevant and non-model fish polar cod (Boreogadus saida) to model carcinogens are required. Polar cod were exposed under laboratory conditions for six months to control, $0.03 \mu \mathrm{g} \mathrm{BaP/g}$ fish/ week and $0.3 \mu \mathrm{g}$ $\mathrm{BaP} / \mathrm{g}$ fish/ week dietary benzo(a)pyrene $(\mathrm{BaP})$, a reference carcinogen. The concentrations of the 3-OH-BaP bile metabolite and transcriptional responses of genes involved in DNA adduct recognition $(x p c)$, helicase activity $(x p d)$, DNA repair (xpf, rad51) and tumour suppression (tp53) were assessed after $0,1,3$ and 6 months of exposure, alongside body condition indexes (gonadosomatic index, hepatosomatic index and condition factor). Micronuclei and nuclear abnormalities in blood and spleen, and liver histopathological endpoints were assessed at the end of the experiment.

Fish grew steadily over the whole experiment and no mortality was recorded. The concentrations of 3-OH-BaP increased significantly after 1 month of exposure to the highest $\mathrm{BaP}$ concentration and after 6 months of exposure to all $\mathrm{BaP}$ concentrations showing the biotransformation of the mother compound. Nevertheless, no significant induction of gene transcripts involved in DNA damage repair or tumour suppression were observed at the selected sampling times. These results together with the absence of chromosomal damage in blood and spleen cells, the subtle increase in nuclear abnormalities observed in spleen cells and the low occurrence of foci of cellular alteration suggested that the exposure was below the threshold of observable effects. Taken together, the results showed that polar cod was not susceptible to carcinogenesis using the $\mathrm{BaP}$ exposure regime employed herein. 
Polycyclic aromatic hydrocarbons (PAHs) are a very large group of ubiquitous organic compounds that can originate from petrogenic, pyrogenic, biogenic and diagenic sources. A number of PAHs are identified as having carcinogenic properties and have been associated to an increased incidence of liver tumours in flatfish in highly polluted environments (Malins $e t$ al., 1985; Myers et al., 1991; Harshbarger and Clark, 1990; Vogelbein et al., 1990; Baumann and Harshbarger, 1998). This pathology has been used to monitor the effects of exposure to PAHs and the health of marine ecosystem since the 1980s (Malins et al., 1985; Veethaak and Ap Rheinallt, 1992) and its assessment recommended by the International Council for Exploration of the Sea (ICES) and the Oslo and Paris Convention (OSPAR) Joint Assessments and Monitoring Programme (JAMP) (Lyons et al., 2010). Benzo(a)pyrene $(\mathrm{BaP})$ is a well-known pyrogenic carcinogen in a plethora of animals such as marine mammals (Acevedo-Whitehouse et al., 2018; Poirier et al., 2019), fish (Wang et al., 2010; Wills et al., 2010) and mice (Kasala et al., 2015; Chen et al., 2019). The reference oral dose below which no effect is expected is $3.10^{-4} \mu \mathrm{g} \mathrm{BaP} / \mathrm{g}$ per day, based on animal and human studies (reviewed in EPA/635/R-17/003). The metabolites generated by endogenous metabolism (biotransformation) are highly genotoxic. Phase I biotransformation of $\mathrm{BaP}$ is mediated by cytochrome $\mathrm{P} 450$ (CYP) enzymes and produces highly reactive metabolic intermediates such as diol-epoxide, dihydrodiol and 3-hydroxybenzo(a)pyrene (3OH-BaP) (Karle et al., 2004; Zhu et al., 2008; Rey-Salgueiro et al., 2011). Those metabolites form DNA adducts that interfere with DNA repair and replication (Phillips and Arlt, 2007). This represents a critical event in the initiation of tumorigenesis, potentially leading to mutations within specific regions of DNA, such as proto-oncogenes and tumour suppressor genes (Rotchell et al., 2001, Du Corbier et al., 2005, Lerebours et al., 2014, 2016). The carcinogenicity of BaP has been well studied in several temperate fish species where specific 
DNA adducts are used as markers for exposure and potential genotoxic effects. Exposure to

77 BaP specifically caused DNA adducts in fish such as pale chub (Zacco platypus) (Lee et al., 2014) and killifish species (Fundulus grandis and F. similis) (Willett et al., 1995; Rose et al., 2000, 2001). Moreover, BaP exposure was associated with neoplastic lesions in brown bullhead (Ameiurus nebulosus) (Ploch et al., 1998), English sole (Parophrys vetulus) (Reichert et al., 1998) and rainbow trout (Hendricks et al., 1985). PAH-induced lesions have also recently been suggested in marine mammals such as harbour porpoises (Phocoena phocoena) (Acevedo-Whitehouse et al., 2018) and beluga whales (Poirier et al., 2019). Pollution induced cancer affects many aquatic species and represents a growing concern for aquatic wildlife (for a review see Baines et al., 2021).

Tumourigenesis is a progressive process characterised by different stages for which the underlying molecular steps and the role of environmental exposure are not always wellknown. Nonetheless, liver tumourigenesis has been well studied in flatfish (Stentiford et al., 2010; Lerebours et al., 2013; 2014; 2017) and in the model fish Japanese medaka (Oryzias latipes) (Rotchell et al., 2001) and zebrafish (Danio rerio) (Li et al., 2017; 2019). DNA repair mechanisms have been associated with tumour formation perturbing several steps of the nucleotide excision repair (NER) pathway, which recognises and repairs DNA adducts induced by numerous environmental mutagens, including PAHs (Gillet and Scharer, 2006; Rastogi et al., 2010). While such mechanisms involved in the development of tumours in certain fish species are well characterised, a substantial knowledge gap exists for non-model and ecologically important species inhabiting remote regions in particular. The Arctic is currently experiencing a rapid decline in sea ice (Kumar et al., 2021) that may lead to a significant increase in marine shipping (Ho et al., 2010), oil and gas exploration and operation (Elias, 2018), and tourism (Meier et al., 2014) and associated release of potential carcinogenic contaminants (Elias, 2018). The polar cod (Boreogadus saida) is a keystone fish 
species in the arctic marine ecosystem due to its abundance, distribution and central role in the food web (Welch et al., 1992). Polar cod has been considered a model fish for arctic ecotoxicology studies (Jonsson et al., 2010; Nahrgang et al., 2009, 2010a,b,c). The toxicity of petroleum compounds on the physiology of polar cod has been well studied (Geraudie et al., 2014; Bender et al., 2016; Nahrgang et al., 2016; Vieweg et al., 2018; Nahrgang et al., 2019) but the tumourigenic potential of a potent carcinogen remains unknown in that species. A few studies however have reported a potential susceptibility to carcinogenic contaminants including $\mathrm{BaP}$. The hepatic metabolism of $\mathrm{BaP}$ is particularly efficient in polar cod and a significant increase of covalently bound reactive intermediates of $\mathrm{BaP}$ in the bile of fish has been found after dietary exposure to $\mathrm{BaP}$ (Ingebrigtsen et al., 2000; Bakke et al., 2016). These reactive intermediates were found to induce the formation of DNA adducts in the liver of that species (Aas et al., 2003). This genotoxic effect can in turn result in cellular abnormalities and cancer initiation. Finally, a recent study showed that expression of genes involved in DNA repair and cell cycle regulation processes was modified in liver of polar cod dietary exposed to BaP (Song et al., 2019).

In order to evaluate the susceptibility of polar cod to a carcinogenic compound, adult specimens were exposed under laboratory conditions for six months to control, $0.03 \mu \mathrm{g} \mathrm{BaP/}$ $\mathrm{g}$ fish/ week and $0.3 \mu \mathrm{g} \mathrm{BaP/g}$ fish/ week dietary BaP. Selected body condition indexes, bile metabolite concentrations and transcriptional responses of genes involved in DNA adduct recognition $(x p c)$, helicase activity $(x p d)$, DNA repair $(x p f$, rad51) and tumour suppression (tp53) were assessed after 0, 1, 3 and 6 months of exposure. Blood and spleen micronuclei, nuclear abnormalities and liver histopathological endpoints were assessed at the end of the experiment.

The sampling times were selected because carcinogenesis is a long-term process. They were comparable to the exposure durations used in several studies interested in 
carcinogenesis in European eel (Nogueira et al., 2006), brown bullhead and channel catfish

127 (Ploch et al., 1985) rainbow trout (Hendricks et al., 1985, Black et al., 1985) and coho salmon (Black et al., 1985) exposed to BaP. The BaP doses selected were lower than the concentrations frequently used in previous studies. They were 10 and 100 times lower than

130 the concentration of $3 \mu \mathrm{g} \mathrm{BaP} / \mathrm{g}$ of fish /week (Colli-Dula et al., 2018) that induced a decrease of body indexes in Nile tilapia after one month of exposure. In addition, our highest concentration was 4 times lower than the lowest concentration used in the study of Song et al., (2019) that found gene expression changes in polar cod after two weeks of exposure, a twelve times shorter exposure duration.

\section{Methods}

Fish collection and exposure

Adult polar cod (4 years old) were collected along the west coast of the Svalbard archipelago (Norway) onboard RV Helmer Hanssen in January 2014 using a Campelen bottom trawl (at 200m depth) and a fish-lift (Holst and McDonald, 2000). At the Troms $\emptyset$ aquaculture research station (Havbrukstasjon i Troms $\varnothing$ ), fish were kept in $3000 \mathrm{~L}$ acclimation tank under a natural light and temperature $\left(1.5-3{ }^{\circ} \mathrm{C}\right)$ regime of $79^{\circ} \mathrm{N}$ (based on mooring data in Wallace et al., 2010). During this period, fish were fed until satiation with thawed Calanus sp. copepods (Calanus AS, Troms $\emptyset)$. Ninety fish were selected based on similar length $(15 \pm 1 \mathrm{~cm})$ and weight $(25 \pm 7 \mathrm{~g})$ for the experiment (June 2014).

Polar cod were dietarily exposed to $0,0.03$ and $0.3 \mu \mathrm{g}$ BaP per gram fish per week,

147 for 6 months ( $2^{\text {nd }}$ of July 2014 to $31^{\text {st }}$ January 2015). The experiment was conducted in 148 compliance with the policies of the Norwegian animal welfare authorities (application ID 149 6571). Briefly, a BaP (Sigma Aldrich, St. Louis, USA) solution in acetone was mixed with 150 Calanus spp (Calanus AS) to yield 0.5 or $5 \mu \mathrm{g}$ BaP per g feed or acetone alone (acetone 
control). The acetone was volatilized by constant stirring on a magnetic stirrer for 2.5 hours at $30{ }^{\circ} \mathrm{C}$. Small pellets were then created with the addition of $0.5 \mathrm{~mL}$ gelatin per $\mathrm{g}$ feed. Fish were fed pellets corresponding to $4 \%$ of their body wet weight (bw) 5 days a week. On the

154 first, third and fifth day of a week, fish were exposed to dietary $\mathrm{BaP}$ or a solvent control by receiving the $2 \%$ bw exposed feed (or solvent control) and $2 \%$ bw of unexposed feed (no $\mathrm{BaP}$, no acetone). Feeding was done by distributing the pellets to the surface of the tank. Thus, feeding hierarchies may have occurred resulting in some intra-tank individual exposure variations. On the remaining 2 days of a week, all fish were fed $4 \%$ bw of unexposed feed. The amount of food given to each tank was adjusted at each sampling point to account for

160 both growth and sampling of specimens. With this feeding regime, the fish nominally 161 received an average of $0,0.03$ and $0.3 \mu \mathrm{g} \mathrm{BaP}$ per gram of fish per week. After $1\left(2^{\text {nd }}\right.$ 162 August), 3 ( $3^{\text {rd }}$ October) and $6\left(31^{\text {th }}\right.$ of January) months, 10 fish per condition were 163 anaesthetized and killed by a sharp blow to the head. Total body weight $(\mathrm{g})$ and fork length $(\mathrm{cm})$ were measured and the presence of parasites recorded. Liver and gonads were removed and weighed. Bile was snap frozen in liquid nitrogen and stored at $-80^{\circ} \mathrm{C}$ until $3-\mathrm{OH} \mathrm{BaP}$ metabolite determination. A liver section was snap frozen in liquid nitrogen and stored at $80^{\circ} \mathrm{C}$ for molecular analyses. During the final sampling (6 months of exposure), a standardized liver cross-section was fixed for $24 \mathrm{hrs}$ in neutral buffered formaldehyde (4\%) before being transferred to $70 \%$ ethanol for subsequent histological assessment. Blood and spleen samples were preserved in Carnoy solution (3 methanol: 1 acetic acid) and stored at $+4^{\circ} \mathrm{C}$ for subsequent identification of nuclear abnormalities and micronuclei. Finally, somatic weight (g) was determined as weight of eviscerated fish. Gonadosomatic index (GSI) and hepatosomatic index (HSI) were calculated as follows: 
177 Biliary 3-OH-benzo[a]pyrene metabolite concentration was determined after 1,3 and 6 178 months of exposure following the procedure detailed in Song et al., (2018). Preparation of 179 hydrolysed bile samples was performed as described in Krahn et al., (1992). Briefly, bile (1$20 \mu \mathrm{L}$ ) was mixed with an internal standard (triphenylamine) and diluted with demineralised water (10-50 $\mu \mathrm{L})$ and hydrolysed with $\beta$-glucuronidasearylsulphatase $(20 \mu \mathrm{L}, 1 \mathrm{~h}$ at 37 C). Methanol (75-200 $\mu \mathrm{L})$ was added and the sample was mixed thoroughly before centrifugation. The supernatant was then transferred to vials and analysed. High pressure

184 liquid chromatography (Waters 2695 Separations Module) was used to separate 3-OH-BaP in 185 a Waters PAH C18 column $(4.6 \times 250 \mathrm{~mm}, 5 \mu \mathrm{m}$ particle size $)$. The mobile phase consisted 186 of a gradient from 40:60 acetonitrile:ammonium acetate $(0.05 \mathrm{M}, \mathrm{pH} 4.1)$ to $100 \%$ acetonitrile at a flow rate of $1 \mathrm{~mL} / \mathrm{min}$, and the column was heated to $35^{\circ}$ C. A 2475 fluorescence detector measured fluorescence at the optimum for each analyte 189 (excitation/emissions: 380/430). A total of $25 \mu$ L extract was injected for each analysis. The results were calculated by use of the internal standard method (Grung et al., 2009). The 191 calibration standards utilized were obtained from Chiron AS, Trondheim, Norway, and were in the range $0.2-200 \mathrm{ng} / \mathrm{g}$. Values below the limit of detection were considered as equal to 0

$193 \mathrm{ng} / \mathrm{g}$ in the analyses.

194 Histopathological analyses

195 Livers were processed in a vacuum infiltration processor (Shandon Citadel 1000) using 196 standard histological protocols (Feist et al., 2004). The tissues were embedded in paraffin 197 using an STP-120 spin tissue processor (Thermo Fisher Scientific, USA). Sections of $4 \mu \mathrm{m}$ 198 thickness were cut using a microtome HM 450 (Thermo Fisher Scientific, USA) and 199 subsequently stained with haematoxylin and eosin (H\&E). The liver sections were examined 
200 for microscopic pre-tumour and tumour lesions according to BEQUALM and ICES criteria

201 (Feist et al., 2004). The pre-tumour lesions sought were the vacuolated, basophilic and

202 eosinophilic foci of cellular alteration (FCA). Tumour lesions were the benign hepatocellular

203 adenoma and the malignant hepatocellular carcinoma (HCC). Lesions associated to nuclear

204 and cellular polymorphism, cell death, inflammation and regeneration were also examined. A

205 total of 5, 6 and 4 fish were assessed from control, low and high exposure condition, 206 respectively.

207

208

209

210

211

212

213

\section{Micronucleus test and nuclear abnormalities}

The micronuclei and nuclear abnormalities frequencies were measured in blood and spleen of polar cod tissues fixed in Carnoy's solution; subsequently separated cells were dispersed on glass slides, and stained with the fluorescent dye 4',6-diamidino- 2-phenylindole at $100 \mathrm{ng} /$ $\mathrm{mL}$. For each experimental condition, a range of 6 to 8 fish were investigated, and for each specimen 2000 cells with preserved cytoplasm were scored to assess the presence of micronuclei and nuclear abnormalities. Micronuclei are defined as round structures, smaller than $1 / 3$ of the main nucleus diameter, on the same optical plan and clearly separated from nucleus; Nuclear abnormalities include (i) binucleated: cell with two nuclei, (ii) notch nuclei: looks like nucleus but do not have nuclear materials, (iii) nuclear bud: evagination of bud-like structure from the nucleus, and (iv) blebbed nuclei: small euchromatin evagination of the nuclear membrane (Gorbi et al., 2009; Islam et al., 2021).

\section{Gene expression analyses}

Following 1, 3 and 6 months of exposure, a cross section of each liver, next to the one dedicated to histological analyses at 6 months was used for gene transcriptional response analyses. Total RNAs were extracted using the High Pure RNA Tissue kit (Roche Diagnostics Ltd, West Sussex, U.K.) according to the supplier's instructions which included a DNase treatment. RNA quality (integrity of $18 \mathrm{~S}$ and $28 \mathrm{~S}$ ribosomal bands) was evaluated 
225 by electrophoresis on a $1 \%$ agarose-formaldehyde gel. RNA purity was assessed by measuring the ratios of absorbance: $\mathrm{A}_{260} / \mathrm{A}_{280}$ and $\mathrm{A}_{260} / \mathrm{A}_{230}$ using a spectrophotometer

227 (NanoDrop, ThermoFisher). All samples were of high purity (ratios' values > 2.1).

First strand cDNAs were synthesized from $1 \mu \mathrm{g}$ of total RNA using the AffinityScript Multiple Temperature cDNA Synthesis Kit (Agilent Technologies, Stockport, U. K.) using random hexamer primers and according to the supplier's instructions. Putative coding sequences (Figure S1) were identified by nucleotide and protein BLAST searches on the NCBI database (http://blast.ncbi.nlm.nih.gov/Blast.cgi) and sequence homologies across fish species on the EMBL-EBI platform (https://www.ebi.ac.uk/Tools/msa/clustalo/). The contigs produced in the study of Song et al., (2019) were also used. Primer pairs and FAMTM_ TAMRA $^{\text {TM }}$ dye probes used to amplify the target sequences were designed using the Prime Express software (Applied Biosystem) (Table 1). Ten ng of the reverse transcribed product measured by a qubit fluorometer (Thermo Fisher Scientific) was used as a template for subsequent polymerase chain reaction (PCR) in a $20 \mu \mathrm{L}$ final volume using $1 \mathrm{x}$ of TaqMan® Fast Advanced Master Mix (Life technologies, Paisley, U.K.), $900 \mathrm{nM}$ primers and $250 \mathrm{nM}$ probe (final concentrations) according to the supplier's protocol. PCR reactions were performed in the Applied Biosystems ${ }^{\mathrm{TM}}$ ViiA $^{\mathrm{TM}} 7$ Real-Time PCR System using the following programme: one cycle at $95^{\circ} \mathrm{C}$ for $20 \mathrm{~s}$ and 40 amplification cycles at $95^{\circ} \mathrm{C}$ for $3 \mathrm{~s}$ and $60^{\circ} \mathrm{C}$ for $30 \mathrm{~s}$. Primer efficiencies were determined by 10 times dilution series of the cDNA template and were about $100 \%$. The optimal normalization gene was selected by testing the expressions of 3 reference genes ( $\beta$ tubulin, hprtl and $28 S$ ) on all the samples using the NormFinder algorithm. The expression of the $\beta$ tubulin gene displayed the highest stability. The melting curves were carefully checked after each qPCR run. The gene expression was calculated according to the delta delta $\mathrm{Ct}$ method. 
251 Statistical analyses were performed using R (version 3.1.2). The effect of the BaP exposure

252 concentration and time of exposure were assessed on all the biological parameters measured 253 using 1-way ANOVA. When the normality of the residuals was not verified by the Shapiro-

254 Wilk test, the non-parametric Kruskal-Wallis tests were used. Post-hoc comparisons were 255 performed using the least-square mean test for parametric test and the Wilcoxon rank test for 256 non-parametric test. The $\alpha$ error was adjusted using the Bonferroni correction for each post-

257 hoc test.

\section{Results}

259 Over the course of the six-month exposure, all specimens grew significantly in weight and underwent gonadal maturation with mean GSI ranging from $1.5 \pm 0.7$ to $20.8 \pm 3.9 \%$ (Table 2). Endoparasites were commonly found across all treatments and sampling times. Nematodes on the liver surface were the most common parasites with a frequency of occurrence of $26 \%$. Parasites of the phylum Platyhelminthes were less common (7\%). No mortality was observed.

The dietary $\mathrm{BaP}$ exposure of polar cod led to a dose-dependent production of biliary 3-OH BaP metabolites for the low $(0.03 \mu \mathrm{g} \mathrm{BaP} / \mathrm{g}$ of fish/week) and high $(0.3 \mu \mathrm{g} \mathrm{BaP} / \mathrm{g}$ of fish/week) $\mathrm{BaP}$ exposure conditions after 1 and 6 months of exposure (Figure 1). The concentrations of bile 3-OH BaP ranged from 20 to $40 \mathrm{ng} / \mathrm{g}$ of bile for the low exposure condition and were approximately 10 times higher, from 132 to $390 \mathrm{ng} / \mathrm{g}$ of bile, for the highest exposure condition.

The transcriptional responses related to DNA adduct recognition $(x p c)$, helicase 272 activity $(x p d)$, DNA repair (xpf, rad51) and tumour suppression (tp53) were not significantly 273 changed by any BaP dietary exposures as compared to controls $(p>0.05)$ (Figure 2). 

exposed to BaP did not significantly vary as compared to control (Figure 3 A, B). Nuclear

276 abnormalities in polar cod spleen were significantly increased in the high dose group $(p=$ 0.03 ), while close to significant in the low dose group $(p=0.057)$ (Figure $3 \mathrm{C}, \mathrm{D})$. No significant nuclear abnormalities were observed after BaP exposure in blood cells $(p>0.05)$. Histopathological analyses revealed one basophilic focus of cellular alteration in liver of two individuals exposed to the low exposure condition after six months of exposure (Figure S2). No tumour-related lesions were observed in livers of control and highly exposed individuals.

\section{Discussion}

The present study showed that polar cod grew steadily through the entire experiments for all exposure conditions $(0,0.03$ and $0.3 \mu \mathrm{g} \mathrm{BaP} / \mathrm{g}$ of fish/ week). These results were expected under chronic low dose exposure scenarios and are consistent with similar results obtained in polar cod exposed to higher dietary $\mathrm{BaP}$ concentrations (1.2 and $60.9 \mu \mathrm{g} \mathrm{BaP} / \mathrm{g}$ of fish/ week) but for a shorter period of two weeks (Song et al., 2019). In Nile tilapia exposed to intraperitoneal injections of $3 \mu \mathrm{g} \mathrm{BaP} / \mathrm{g}$ of fish/ week for 4 weeks, K, GSI and GSI were slightly decreased (Colli-Dula et al., 2018). This suggests that there is a dose and time dependent threshold above which exposure to $\mathrm{BaP}$ induce significant body condition indexes changes. The fish species and the mode of $\mathrm{BaP}$ administration (injected intraperitoneally versus dietary) may also be important factors to consider.

The bile concentration of 3-OH-BaP has been used as an indicator of $\mathrm{BaP}$ exposure and biotransformation in many fish species including polar cod (Baake et al., 2016; Baali et al., 2016; Kammann et al., 2017; Song et al., 2019). Indeed, previous studies led on polar cod exposed to either PAHs or crude oil have shown a very high correlation between bile metabolites of PAHs and both cyp1a mRNA expression and EROD activity (Bakke et al., 

increase in biliary 3-OH-BaP metabolite concentrations after 1 and 6 months exposure supported that of a similar, albeit shorter, exposure study (Song et al., 2019). When exposed to a four times higher exposure dose $(1.2 \mu \mathrm{g} \mathrm{BaP} / \mathrm{g}$ of fish/ week) than the highest dose used in the present study, a 3-OH-BaP concentration of $800 \mathrm{ng} / \mathrm{g}$ of bile was found, which was two to six times higher than the metabolite concentration range identified in our study. The reactive $\mathrm{BaP}$ intermediates have been found to accumulate and covalently bind DNA in the biliary system of polar cod one month after exposure to a single dietary concentration (Baake et al., 2016) equivalent to the cumulative dose received in the high $\mathrm{BaP}$ exposure condition during the first month of our study. Those reactive $\mathrm{BaP}$ metabolites covalently bind to biological molecules such nucleic acids and form DNA adducts that can lead to tumour formation. For instance, higher levels of BaP-7,8-diol metabolites and DNA binding activity were found in bile of English sole (Parophrys vetulus) a fish species more sensitive to carcinogenesis than the more resistant starry flounder (Platichthys stellatus) (Varanasi et al., 1986). In polar cod dietarily exposed to higher $\mathrm{BaP}$ concentrations (from $5 \mu \mathrm{g} \mathrm{BaP} / \mathrm{g}$ of fish in a single injection) DNA adducts were found (Aas et al., 2003), revealing an increased risk of liver tumour formation later on. Indeed, $50 \%$ of rainbow trout displayed pre-tumour (basophilic FCA) and tumour (HCC) liver lesions after six months of exposure to a similar dose injected intraperitoneally (Hendricks et al., 1985). In their study, $25 \%$ of the trouts

318 displayed similar liver lesions after twelve months of dietary exposure to a high dose of BaP 319 (estimated to $1-2 \mathrm{mg} \mathrm{BaP} / \mathrm{g}$ fish/ week) (Hendricks et al., 1985). In the present study, the potential genotoxic damage generated by the $\mathrm{BaP}$ metabolites produced did not cause significant tumour lesions. This could be the result of several factors potentially in combination, including low dose, low exposure duration and effective DNA repair mechanisms. 

onset of tumorous events. In the present study, the transcriptional response of genes involved in the nucleotide excision repair (NER) process $(x p c, x p d, x p f)$, DNA double strand breaks repair ( $\mathrm{rad51})$ and cell division regulation (tp53) did not vary significantly after 1,3 , and 6 months of exposure to both $\mathrm{BaP}$ dietary concentrations. The exposure levels of $\mathrm{BaP}$ may have been too low to cause significant accumulation of cell damage and trigger a significant gene transcriptional response. Interestingly, a dose-specific transcriptional response of some genes has been observed in liver of polar cod dietary exposed to BaP (Song et al., 2019). For instance, some genes involved in apoptosis (bax and casp9), a process that eliminates damaged cells and prevent the proliferation of abnormal cells in tumour formation, were upregulated in polar cod exposed to the high exposure level (60.9 $\mu \mathrm{g} \mathrm{BaP/g}$ of fish/ week). The expression levels of those genes were not modified in fish exposed to the low exposure dose (1.2 $\mu \mathrm{g} \mathrm{BaP/g}$ of fish/week) suggesting a threshold above which gene transcription is modified (Song et al., 2019). The basal gene expression level may also be sufficient to repair DNA and/or delay the cell cycle to maintain the genetic integrity. Moreover, the DNA repair gene measured in our study, rad51, may not be involved in the repair of specific DNA damage induced. Similarly to the results herein, this gene was not differentially expressed in

341 liver of polar cod dietary exposed to BaP (Song et al., 2019). Rad51 is involved in the repair 342 of DNA double strand breaks, which belong to a different pathway than the NER. The 343 mechanism of DNA damage induced by BaP exposure is more likely to involve DNA 344 adducts than double strand breaks. Other genes involved in DNA repair processes and control 345 of cell cycle have been found induced at higher exposure regimes. For example, the gene encoding for the growth arrest and DNA damage inducible beta gene (gadd45b) was induced

347 in the liver of the tropical fish, Nile Tilapia (Oreochromis niloticus) after one month of 348 exposure to $3 \mu \mathrm{g} \mathrm{BaP} / \mathrm{g}$ of fish/week (Colli-Dula et al., 2018). In polar cod exposed to 1.2 
and $60.9 \mu \mathrm{g} \mathrm{BaP} / \mathrm{g}$ of fish/ week, genes involved in the excision DNA repair process (such as $h m g b 2 b$ and $\mathrm{rad} 23 a$ ) were differentially expressed (Song et al., 2019). Shorter timepoints may have also been necessary to observe a gene expression modulation as an early response to stressors. In the liver of polar cod, transcriptional responses of genes involved in DNA 353 damage repair were changed after two weeks of dietary exposure to BaP (Song et al., 2019).

354 Some studies using a reference genotoxic compound showed that DNA damage was rapidly repaired with increased transcription of DNA repair genes such as rad51 in zebrafish larvae, as early as 6 hours (Reinardy et al. 2013). The addition of early sampling times seems relevant to include in future studies.

Other biological processes such as detoxification mechanisms could have prevented polar cod from the genotoxic effects of $\mathrm{BaP}$ exposure. Activation of detoxification events could explain the resistance of polar cod to $\mathrm{BaP}$ exposure and the absence of liver tumours in the present study. Variation in the expression of genes and proteins belonging to the cytochrome P450 family involved in phase I of BaP detoxification process has been well described in liver of fish (Nahrgang et al., 2009; Lee et al., 2014; Colli-Dula et al., 2018). Interestingly, cyplal and cyplbl genes were upregulated in liver of polar cod following dietary exposure to $60.9 \mu \mathrm{g} \mathrm{BaP} / \mathrm{g}$ of fish/ week but were not differentially expressed after exposure to a lower dose of $\mathrm{BaP}(1.2 \mu \mathrm{g} \mathrm{BaP} / \mathrm{g}$ of fish/ week) (Song et al., 2019). This suggests a dose threshold for activating the detoxification mechanisms during a chronic exposure. Activation of genes and proteins involved in phase II detoxification process has

369 been also described in liver of fish exposed to BaP (Nahgang et al., 2009). For instance, gstAl gene expression was modified in the liver of Nile tilapia exposed to $3 \mu \mathrm{g} \mathrm{BaP} / \mathrm{g}$ of

371 fish/ week (Colli-Dula et al., 2018). Interestingly, GST activity was higher in starry flounder,

372 a tumour resistant species, than in English sole, a tumour sensitive species, after exposure to 373 a BaP dose that induced carcinogenesis (Varanasi et al., 1987). Finally, phase III 
374 detoxification process based on active efflux of chemicals by ATP-binding cassette (ABC)

375 transporters could be involved in $\mathrm{BaP}$ elimination. For example, a rainbow trout ABCG2

376 transporter was found to interact with BaP (Zaja et al., 2016).

In accordance with relatively low biliary $\mathrm{BaP}$ metabolite concentrations observed

378 throughout the exposure and limited responses of genes involved in DNA damage

379 identification and repair, no effect of dietary $\mathrm{BaP}$ on the micronuclei and nuclear

380 abnormalities was recorded in the present study except in spleen where nuclear abnormalities

381 increased in the high dose group. Micronuclei are formed during the anaphase stage of the

382 cell division. They are considered as a reliable index of chromosomal breakage,

383 chromosomal loss and cellular spindle malfunction (Bolognesi and Hayashi, 2011).

384 Additionally, micronuclei constitute an irreversible form of genotoxic damage compared to

385 DNA strand breaks and their induction are regulated by a large number of experimental

386 carcinogens, including chlorinated hydrocarbons, benzidine, aflatoxins, methylcholanthrene,

387 and common carcinogenic pollutants, such as PAHs, heavy metals, and pesticides (Bolognesi

388 and Hayashi, 2011). Many research studies reported the increased in micronuclei frequency

389 in erythrocytes of different fish species exposed to PAHs (Shirmohammadi et al., 2018).

390 Contrary to micronuclei, nuclear abnormalities origin has not been clearly explained; some suggest that nuclear abnormalities can be a primary response, prior to the micronuclei

392 formation, highlighting their relevance in the evaluation of genotoxic damage (Bolognesi and

393 Hayashi, 2011; Seriani et al., 2011). An increase of erythrocytic nuclear abnormalities and

394 strand breaks was observed in eels (Anguilla anguilla L.) and juvenile sea bass

395 (Dicentrarchus labrax) exposed to a range of 0.3 to $2.7 \mu \mathrm{M}$ of BaP and naphthalene (Maria et

396 al., 2002; Teles et al., 2003; Gravato and Santos, 2002), while on the contrary, lower

397 concentrations of $\mathrm{BaP}(0.1 \mu \mathrm{M})$ did not affect DNA integrity (Nogueira et al., 2006). The

398 induction of micronuclei and other nuclear abnormalities were also caused by crude oil 
exposure in turbot (Scophthalmus maximus) and Atlantic cod (Gadus morua) (Baršienè et al.,

400 2004; 2006). The exposure duration and levels are extremely important in determining

401 micronuclei and nuclear abnormalities formation; long-term chemical exposures can cause

402 genetic changes and consequently physiological alterations or pathologies including cancer

403 development (Depledge and Hopkin, 1995). In a study led on the European flounder,

404 Platichthy flesus, Köhler and Ellesat, (2008), first suggested that nuclear anomalies inside

405 liver lesions of hepatocellular cancers were correlated with micronuclei frequencies in fish

406 blood and that the histopathological grading of cancers from preneoplastic, benign to

407 malignant types was clearly associated with micronuclei increase.

408 The present study showed that polar cod were consistently exposed to dietary BaP

409 through the entire experiment and biotransformed the mother compound to intermediate

410 metabolites. However, this exposure did not lead to significant changes in the transcription of

411 selected genes, nor in chromosomal alterations and significant tissue lesions. Some early

412 responses to stress may have occurred prior to the first sampling time point at one month of

413 exposure, and basal expression of genes or potentially activated compensatory mechanisms

414 may have been sufficient to control the damage caused by the reactive metabolites.

415 Moreover, protective mechanisms such as detoxification and apoptosis could have prevented

416 the cells from the accumulation of cell damage caused by the reactive metabolites. Therefore,

417 we deduce that the $\mathrm{BaP}$ exposure concentrations were below the threshold of observable

418 effects. As a whole, our results showed that polar cod exposed to 0.03 and $0.3 \mu \mathrm{g} \mathrm{BaP} / \mathrm{g}$ fish/

419 week was not sensitive to the model carcinogen and liver carcinogenesis. The present work

420 encourages the addition of earlier sampling points and indicators of detoxification

421 mechanisms in future studies.

422

423 


\section{References}

432

433 Aas E, Liewenborg B, Grøsvik BE, Camus L, Jonsson G, Børseth JF, Balk L. 2003. DNA 434 adduct levels in fish from pristine areas are not detectable or low when analysed using the 435 nuclease P1 version of the ${ }^{32} \mathrm{P}$-postlabelling technique. Biomarkers, 8: 445-460.

436

437 Acevedo-Whitehouse K, Cole KJ, Philips DH, Jepson PD, Deaville R, Arlt VM. 2018. 438 Hepatic DNA Damage in Harbour Porpoises (Phocoena phocoena) Stranded along the 439 English and Welsh Coastlines. Environmental and Molecular Mutagenesis, 59: 613-624.

440

441 Baali A, Kammann U, Hanel R, El Qoraychy I, Yahyaoui A. 2016. Bile metabolites of 442 polycyclic aromatic hydrocarbons (PAHs) in three species of fish from Morocco. 443 Environmental Sciences Europe. 28, 25.

445 Baines C, Lerebours A, Thomas F, Fort J, Kreitsberg R, Gentes S, Meitern R, Saks L, Ujvari 446 B, Giraudeau M, Stepp T. 2021. Linking pollution and cancer in aquatic environments: A 447 review. Environment International 149: 106391. 
449 Bakke MJ, Nahrgang J, Ingebrigtsen K. 2016. Comparative absorption and tissue distribution

450 of ${ }^{14} \mathrm{C}$-benzo(a)pyrene and ${ }^{14} \mathrm{C}$-phenanthrene in the polar cod (Boreogadus saida) following 451 oral administration. Polar biology, 39: 165-1173.

452

453 Baršienė J, Dedonytė V, Rybakovas A, Andreikènaitè L, Andersen OK. 2006. Investigation 454 of micronuclei and other nuclear abnormalities in peripheral blood and kidney of marine fish 455 treated with crude oil. Aquatic Toxicology, 78: S99-S104

456

457 Baršienė J, Lazutka J, Šyvokienė J, Dedonytė V, Rybakovas A Bagdonas E, Bjornstad A, 458 Andersen OK. 2004. Analysis of micronuclei in blue mussels and fish from the Baltic and 459 North Seas. Environmental Toxicology, 19: 365-371.

460

461 Baumann, PC, Harshbarger JC. 1998. Long term trends in liver neoplasm epizootics of brown 462 bullhead in the Black River, Ohio. Environmental Monitoring and Assessment 53: 213-223.

464 Bender ML, Frantzen M, Vieweg I, Falk-Petersen IB, Johnsen HK, Rudolfsen G, Tollefsen 465 KE, Dubourg P, Nahrgang J. 2016. Effects of chronic dietary petroleum exposure on 466 reproductive development in polar cod (Boreogadus saida). Aquatic Toxicology, 180: 196467208

468

469 Black JJ, Maccubbin AE and Martin M. 1985. A Reliable, Efficient, Microinjection 470 Apparatus and Methodology for the In Vivo Exposure of Rainbow Trout and Salmon 471 Embryos to Chemical Carcinogen. Journal of the National Cancer Institute, 75: 1123-8. 
473 Bolognesi C, Hayashi M. 2011. Micronucleus assay in aquatic animals. Mutagenesis, 26: $474205-213$.

475

476 Chen W, Zhang H and Liu Y. 2019. Anti-Inflammatory and Apoptotic Signaling Effect of 477 Fucoxanthin on Benzo(A)Pyrene-Induced Lung Cancer in Mice. Journal of Environmental 478 Pathology, Toxicology and Oncology, 38: 239-251.

479

480 Colli-Dula RC, Fang X, Moraga-Amador D, Albornoz-Abud N, Zamora-Bustillos R, Conesa 481 A, Zapata-Perez O, Moreno D, Hernandez-Nuñez E. 2018. Transcriptome analysis reveals 482 novel insights into the response of low-dose benzo(a)pyrene exposure in male tilapia. Aquatic 483 Toxicology, 162-173.

484

485

Depledge M.H., Hopkin S.P. 1995. Methods to assess effects on brackish, estuarine, and 486 near-coastal water organisms. Wiley (Ed.), SCOPE 53-Methods to Assess the Effects of 487 Chemicals on Ecosystems, the Scientific Committee On Problems of the Environment 488 (SCOPE).

489

490

Du Corbier, FA, Stentiford GD, Lyons BP, Rotchell JM. 2005. Isolation of the 491 retinoblastoma cDNA from the marine flatfish dab (Limanda limanda) and evidence of 492 mutational alterations in liver tumors. Environmental Science and Technology, 39: 97854939790.

494

495 Elias, 2018. Conservation issues: Tundra ecosystems. Encyclopedia of the Anthropocene, 496 $2,2018,165-175$

497 
EPA/635/R-17/003Fa. Toxicological Review of Benzo[a]pyrene. 2017. U.S. Environmental

Protection Agency Washington, DC.

500

501 Feist SW. 2004. Biological effects of contaminants: use of liver pathology of the European

502 flatfish dab (Limanda limanda L.) and flounder (Platichthys flesus L.) for monitoring 503 (International Council for the Exploration of the Sea, Copenhagen).

504

505 Geraudie P, Nahrgang J, Forget-Leray J, Minier C, Camus L. 2014. In vivo effects of en

506 vironmental concentrations of produced water on the reproductive function of polar cod

507 (Boreogadus saida). Journal of Toxicology and Environmental Health A, 77: 557-573.

508

509 Gillet LCJ and Scharer OD. 2006. Molecular mechanisms of mammalian global genome 510 nucleotide excision repair. Chemical Reviews, 106: 253-276.

511 Gorbi S., Benedetti M., Virno Lamberti C., Pisanelli B., Moltedo G., Regoli F. 2009.

512 Biological effects of diethylene glycol (DEG) and produced waters (PWs) released from 513 offshore activities: A multi-biomarker approach with the sea bass Dicentrarchus labrax.

514 Environmental Pollution, 157: 3166-3173.

515

516 Gravato C, Santos MA. 2002. Juvenile sea bass liver P450, EROD induction, and 517 erythrocytic genotoxic responses to PAH and PAH-like compounds. Ecotoxicology and 518 Environmental Safety, 51:115-127

519

520 Harshbarger JC, Clark JB. 1990. Epizootiology of neoplasms in bony fish of North America.

521 Science of the Total Environment, 94: 1-32.

522 
523 Hendricks JD, Meyers TR, Shelton DW, Casteel JL, Bailey GS. 1985. Hepatocarcinogenicity

524 of benzo[a]pyrene to rainbow trout by dietary exposure and intraperitoneal injection. Journal 525 of national cancer institute, $74: 839-851$.

526

527 Ho, J. 2010. The implications of Arctic sea ice decline on shipping. Marine Policy, 34 : $713-$ 528715.

529

530

Holst, JC, McDonald, A. 2000. Fish-lift: a device for sampling live fish with trawls. Fish.

531 Research, $48: 87-91$.

532

533 Ingebrigtsen K, Christiansen JS, Lindhe Ö, Brandt I. 2000. Disposition and cellular

534 binding of ${ }^{3} \mathrm{H}$-benzo(a)pyrene at subzero temperatures: studies in an aglomerular arctic 535 teleost fish - the polar cod (Boreogadus saida). Polar Biology, 23: 503-509.

536

537 Islam MJ, Slater MJ, Thiele R, Kunzmann A. 2021. Influence of extreme ambient cold stress 538 on growth, hematological, antioxidants, and immune responses in European seabass, 539 Dicentrarchus labrax acclimatized at different salinities. Ecological Indicators, 122: 107280.

540

541 Jonsson H, Sundt RC, Aas E, Sanni S. 2010. The Arctic is no longer put on ice: evalua- tion 542 of polar cod (Boreogadus saida) as a monitoring species of oil pollution in cold waters. 543 Marine Pollution Bulletin, 60: 390-395.

544

545 Kammann U, Akcha F, Budzinski H, Burgeot T, Gubbins MJ, Lang T, Le Menach K,

546 Vethaak AD, Hylland K. 2017. PAH metabolites in fish bile: from the seine estuary to 547 Iceland. Marine Environmental Research, 124: 41-45. 
549 Karle IL, Yagi H, Sayer JM, and Donald MJ. 2004. Crystal and molecular structure of a

550 benzo[a]pyrene 7,8-diol 9,10-epoxide N2-deoxyguanosine adduct: Absolute configuration

551 and conformation. Proceedings of the National Academy of Sciences of the United States of

552 America, 6: 1433-1438.

553

554 Kasala ER, Bodduluru LN, Barua CC, Sriram CS, Gogoi R. 2015. Benzo(a)pyrene induced

555 lung cancer: Role of dietary phytochemicals in chemoprevention. Pharmacological Reports.

556 67: 996-1009.

557

558 Köhler A, Ellesat K. 2008. Nuclear changes in blood, early liver anomalies and 559 hepatocellular cancers in flounder (Platichthys flesus L.) as prognostic indicator for a higher 560 cancer risk? Marine Environmental Research, $66: 149-150$

561

562 Krahn, MM, Burrows DG, Ylitalo GM, Brown DW, Wigren CA, Collier TK, Chan SL,

563 Varanasi U. 1992. Mass-spectrometric analysis for aromatic-compounds in bile of fish 564 sampled after the Exxon-Valdez oil-spill. Environmental Science and Technology, 26: 116565 126.

566

567 Kumar A, Yadav J, Mohan R. 2021. Spatio-temporal change and variability of Barents-Kara

568 sea ice, in the Arctic: Ocean and atmospheric implications. Science of the Total Environment, $569 \quad 753: 142046$.

570

571 Lee, JW, Kim, YH, Yoon, S, Lee SK. 2014. Cytochrome P450 System Expression and DNA

572 Adduct Formation in the Liver of Zacco platypus Following Waterborne Benzo(a)pyrene 
573 Exposure: Implications for Biomarker Determination. Environmental Toxicology, 29: 10325741042.

575

576 Lerebours A, Bignell JP, Stentiford GD, Feist SW, Lyons BP, Rotchell JM. 2013. Advanced 577 diagnostics applied to fish liver tumours: relating pathology to underlying molecular 578 aetiology. Marine Pollution Bulletin, 72 : 94-98.

579

580 Lerebours A, Stentiford GD, Lyons BP, Bignell JP, Derocles SA, Rotchell JM. 2014. Genetic 581 alterations and cancer formation in a European flatfish at sites of different contaminant 582 burdens. Environmental Science and Technology, 48 :10448-10455.

583

584 Lerebours A, Chapman E, Lyons BP, Bignell JP, Stentiford GD, Rotchell JM. 2017. 585 Hepatocellular adenoma in a European flatfish (Limanda limanda): genetic alterations in 586 laser-capture micro-dissected tissue and global transcriptomic approach. Marine Pollution 587 Bulletin, 119: 120-127.

588

589 Li Y, Li H, Spitsbergen JM, Gong Z. 2017. Males develop faster and more severe 590 hepatocellular carcinoma than females in krasV12 transgenic zebrafish. Scientific Reports, 7: 59141280.

592

593 Li H, Li Y, Lu JW, Huo X, Gong Z. 2019. Liver-specific androgen receptor knockout 594 attenuates early liver tumor development in zebrafish. Scientific Reports, 9: 10645. 
596 Lyons, BP, Thain, JE, Stentiford, GD, Hylland, K, Davies, IM, Vethaak, AD. 2010. Using 597 biological effects tools to define Good Environmental Status under the European Union 598 Marine Strategy Framework Directive. Marine Pollution Bulletin, 60 : 1647-1651.

599

600 Malins, DC, Krahn MM, Brown DW, Rhodes LD, Myers MS, Mccain BB, Chan SL. 1985.

601 Toxic-Chemicals in Marine Sediment and Biota from Mukilteo, Washington - Relationships 602 with Hepatic Neoplasms and Other Hepatic-Lesions in English Sole (Parophrys Vetulus). 603 Journal of the National Cancer Institute, 74: 487-494.

604

605 Maria VL, Correia AC, Santos MA. 2002. Anguilla anguilla L. biochemical and genotoxic 606 responses to benzo[a]pyrene. Ecotoxicology and Environmental Safety, 53: 86-92.

607

608 Meier WN, Hovelsrud GK, van Oort BEH, Key JR, Kovacs KM, Michel C, Haas C, Mats A 609 G, Gerland S, Donald KP, Makshtas A, Reist JD. 2014. Arctic sea ice in transformation: A 610 review of recent observed changes and impacts on biology and human activity. Reviews of 611 Geophysics, 51: 185-217

612

613 Myers, MS, Landahl JT, Krahn MM, McCain BB. 1991. Relationships between hepatic 614 neoplasms and related lesions and exposure to toxic chemicals in marine fish from the U.S. 615 west coast. Environmental Health Perspectives, 90: 7-15.

616 Nahrgang J, Camus L, Gonzalez P, Goksøyr A, Christiansen J, Hop H, 2009. PAH biomarker 617 responses in polar cod (Boreogadus saida) exposed to benzo(a)pyrene. Aquatic Toxicology. $61814,309-319$. 
619 Nahrgang J, Camus L, Broms F, Christiansen JS, Hop H. 2010a. Seasonal baseline levels of 620 physiological and biochemical parameters in polar cod (Boreogadus saida): implications for 621 environmental monitoring. Marine Pollution Bulletin, 60: 1336-1345.

622 Nahrgang J, Camus L, Carls MG, Gonzalez P, Jonsson M, Taban IC, Bechmann RK, 623 Christiansen JS, Hop H. 2010b. Biomarker responses in polar cod (Boreogadus saida) 624 exposed to the water soluble fraction of crude oil. Aquatic Toxicology, 97: 234-242.

625 Nahrgang J, Camus L, Gonzalez P, Jonsson M, Christiansen JS, Hop H. 2010c. Biomarker 626 responses in polar cod (Boreogadus saida) exposed to dietary crude oil. Aquatic Toxicology, 627 96: 77-83.

628 Nahrgang J, Dubourg P, Frantzen M, Storch D, Dahlke F, Meador JP. 2016. Early life stages 629 of an arctic keystone species (Boreogadus saida) show high sensitivity to a water-soluble 630 fraction of crude oil. Environmental Pollution, 218: 605-614.

631 Nahrgang J, Bender ML, Meier S, Nechev J, Berge J, Frantzen M. 2019. Growth and 632 metabolism of adult polar cod (Boreogadus saida) in response to dietary crude oil. 633 Ecotoxicology and Environmental Safety, 180: 53-62.

634 Nogueira PR, Lourenço J, Mendo S, Rotchell LM. 2006. Mutation analysis of ras gene in the 635 liver of European eel (Anguilla anguilla L.) exposed to benzo[a]pyrene. Marine Pollution 636 Bulletin, 52: 1611-1616.

637

638 Phillips and Artlt. 2007. The ${ }^{32}$ P-postlabeling assay for DNA adducts. Nature Protocols, 2: $6392772-2781$.

641 Ploch SA, King LC, Kohan MJ, Di Giulio RT.1998. Comparative in Vitro and in Vivo 
642 Benzo[a]pyrene-DNA Adduct Formation and Its Relationship to CYP1A Activity in Two

643 Species of Ictalurid Catfish. Toxicology and applied pharmacology 149: 90-98.

644 Poirier et al 2019. Intestinal Polycyclic Aromatic Hydrocarbon-DNA Adducts in a Population 645 of Beluga Whales with High Levels of Gastrointestinal Cancers Environ Mol Mutagen, 60: $64629-41$.

647

648 Rastogi A, Richa, Kumar A, Tyagi MB, Sinha RP. 2010. Molecular mechanisms of 649 ultraviolet radiation-induced DNA damage and repair. Journal of Nucleic Acids, 2010: 650592980.

651

652

653 Reinardy KC, Dharamshi J, Jha AN, Henry TB. 2013. Changes in expression profiles of 654 genes associated with DNA repair following induction of DNA damage in larval zebrafish 655 Danio rerio. Mutagenesis, 28: 601-608.

656

657 Rei-Salgueiro L, Costa J, Ferreira M Reil-Henriques MA. 2011. Evaluation of 3-hydroxy658 benzo[a]pyrene levels in Nile tilapia (Oreochromis niloticus) after waterborne exposure to 659 Benzo[a]pyrene. Ecotoxicology, 2040-2054.

660

661 Reichert WL, Myers MS, Peck-Miller K, French B, Anulacion BF, Collier TK, Stein JE,

662 Varanasi U. 1998. Molecular epizootiology of genotoxic events in marine fish: Linking 663 contaminant exposure, DNA damage, and tissue-level alterations. Mutation Research, 411: $664 \quad 215-225$

665 
666 Rose, WL, French, BL, Reichert, WL, Faisal, M. 2001. Persistence of benzo[a]pyrene-DNA 667 adducts in hematopoietic tissues and blood of the mummichog, Fundulus heteroclitus. 668 Aquatic Toxicology, 52: 319-328.

669

670 Rose, WL, French, BL, Reichert, WL, Faisal, M., 2000. DNA adducts in hematopoietic 671 tissues and blood of the mummichog (Fundulus heteroclitus) from a creosote-contaminated 672 site in the Elizabeth River, Virginia. Marine Environmental Research, 50: 581-589.

673

674 Rotchell, JM, Blair, JB, Shim, JK, Hawkins, WE, Ostrander, GK. 2001. Cloning of the 675 Retinoblastoma cDNA from the Japanese medaka (Oryzias latipes) and preliminary evidence 676 of mutational alterations in chemically-induced retinoblastomas. Gene, 263: 231-237.

677

678

Seriani R, Tavares Ranzani-Paiva M J., Silva- Souza A. T., Silva Roseli N. 2011. 679 Hematology, micronuclei and nuclear abnormalities in fishes from São Francisco River, 680 Minas Gerais state, Brazil. Acta Scientiarum Biological Sciences. 33: 107-112.

681

682 Shirmohammadi M., Mohammad N. S., Ronagh T., Movahedinia A., Hamidian G. 2018. 683 Using cell apoptosis, micronuclei and immune alternations as biomarkers of phenanthrene 684 exposure in yellowfin seabream (Acanthopagrus latus). Fish and Shellfish Immunology, 72: $685 \quad 37-47$.

686

687 Song Y, Nahrgang Y, Tollefden KE. 2019. Transcriptomic analysis reveals dose-dependent 688 modes of action of benzo(a)pyrene in polar cod (Boreogadus saida). Science of the total 689 environment, 653: 176-189.

690 
691 Stentiford, GD, Bignell, JP, Lyons, BP, Thain, JE, Feist, SW. 2010. Effect of age on liver 692 pathology and other diseases in flatfish: Implications for assessment of marine ecological 693 health status. Marine Ecololy Progress Series, 411: 215-230.

694

695 Teles M, Pacheco M, Santos MA. 2003. Anguilla anguilla L. liver ethoxyresorufin O696 deethylation, Glutathione S-transferase, erythrocytic nuclear abnormalities, and endocrine 697 responses to naphthalene and $\beta$-naphthoflavone. Ecotoxicology and Environmental Safety, 698 55: $98-107$

699

700 Varasini U, Nishimoto M, Reichert WL, Le Eberhart BT. 1986. Comparative Metabolism of 701 Benzo(a)pyrene and Covalent Binding to Hepatic DNA in English Sole, Starry Flounder, and 702 Rat. Cancer Research, 46: 3817-3824.

703

704 Varasini U, Stein JE, Nishimoto M, Reichert WL, Collier TK. 1987. Chemical 705 Carcinogenesis in Feral Fish: Uptake, Activation, and Detoxication of Organic Xenobiotics. 706 Environmental Health Perspectives, 71: 155-170.

707

708

Vethaak, AD, Rheinallt Tap. 1992. Fish disease as a monitor for marine pollution: the case of 709 the North Sea. Reviews in Fish Biology and Fisheries, 2: 1-32.

710

711 Vieweg I, Bilbao E, Meador JP, Cancio I, Bender ML, Cajaraville MP, Nahrgang J. 2018.

712 Effects of dietary crude oil exposure on molecular and physiological parameters related to 713 lipid homeostasis in polar cod (Boreogadus saida). Comparative Biochemistry and 714 Physiology, Part C: Toxicology and Pharmacology. 206-207, 54-64. 
716 Vogelbein, WK, Fournie JW, Van Veld PA, Huggett RJ. 1990. Hepatic neoplasms in the

717 mummichog Fundulus heteroclitus from a creosote-contaminated site. Cancer Research 50:

$718 \quad 5978-5986$.

719

720 Wallace MI, Cottier FR, Berge J, Tarling GA, Griffits C, et al. 2010. Comparison of 721 zooplankton vertical migration in an ice-free and a seasonally ice-covered Arctic fjord: An 722 insight into the influence of sea ice cover on zooplankton behavior. Limnology and

723 Oceanography 55: 831-845.

724

725

Wang L, Camusb AC, Donga W, Thorntona C, Willetta KL. 2010. Expression of CYP1C1 726 and CYP1A in Fundulus heteroclitus during PAH-induced carcinogenesis. Aquatic 727 Toxicology, 99: 439-447.

728

729

Welch HE, Bergmann MA, Siferd TD, Martin KA, Curtis MF, Crawford RE Conover RJ, 730

Hop H. 1992. Energy flow through the marine ecosystem of the Lancaster Sound region, 731 Arctic Canada. Arctic 45, 343-375.

732

733 Willett, K, Steinberg M, Thomsen J, Narasimhan TR, Safe S, McDonald S, Beatty K, 734 Kennicutt, MC. 1995. Exposure of killifish to benzo[a]pyrene: comparative metabolism, 735 DNA adduct formation and aryl hydrocarbon (Ah) receptor agonist activities. Comparative 736 Biochemistry and Physiology. Part B: Biochemistry and Molecular Biology, 112: 93-103. 737

738 Wills, LP, Jung D, Koehrn K, Zhu S, Willett KL, Hinton DE, di Giulio RT. 2010. 739 Comparative chronic liver toxicity of benzo[a]pyrene in two populations of the atlantic 
740 killifish (Fundulus heteroclitus) with different exposure histories. Environmental Health

741 Perspectives, 118: 1376-1381.

742 Zaja R, Popovic M, Loncar J, Smital T. 2016. Functional characterization of rainbow trout 743 (Oncorhynchus mykiss) Abcg2a (Bcrp) transporter. Comparative Biochemistry and 744 Physiology, Part C, 190: 15-2.

745 Zhu S, Li L, Thornton C, Carvalho P, Avery BA, Willett KL. 2008. Simultaneous 746 determination of benzo[a]pyrene and eight of its metabolites in Fundulus heteroclitus bile 747 using ultra-performance liquid chromatography with mass spectrometry. Journal of 748 Chromatography B, 863: 141-149.

\section{Figure and Table Legend.}

752

Figure 1. Concentrations of biliary 3-OH-benzo[a]pyrene (ng/g bile, $n=4$ to 9 ) in fish exposed to three treatments of $\mathrm{BaP}$ (acetone control, low and high) during $0,1,3$ and 6 months. Plots represent the median (line), 25-75\% percentiles (box), non-outlier range (whisker), outliers (circle) and extreme values (coloured triangle). The effect of the dose and

757 time on the metabolite concentrations were assessed using the Kruskal-Wallis rank test.

758 When significant, a Wilcoxon test and a Bonferroni correction were applied. Asterisks (*) show significant difference from the control treatment $(p<0.05)$. Numbers above boxes represent the $n$.

761 Figure 2. Relative expression of genes (mean \pm SD, arbitrary units) in liver of polar cods $(n=$ 76210 per treatment and time) exposed to acetone control, low and high BaP treatments after 1, 3 and 6 months. Plots represent the median (line), 25-75\% percentiles (box), non-outlier range 
764 (whisker), outliers (circle) and extreme values (coloured triangle). The effect of the dose on 765 the gene expression levels was assessed using the Kruskal-Wallis rank test. No significant 766 differences $(p>0.05)$ among treatments were found. Numbers above boxes represent the $n$.

767 Figure 3. DNA damage in the form of micronuclei per thousand in the blood (A) and spleen

768 (B) and nuclear abnormalities in the blood (C) and spleen (D) of polar cod sampled after 6 769 month of exposure. Plots represent the median (line), 25-75\% percentiles (box), non-outlier 770 range (whisker), outliers (circle) and extreme values (coloured triangle). The effect of the 771 dose on the number of micronuclei and nuclear abnormalities was assessed using the 772 Kruskal-Wallis rank test. When significant, a Wilcoxon test and a Bonferroni correction were 773 applied. Asterisks $\left(^{*}\right)$ show significant difference from the control treatment $(p<0.05)$.

774 Numbers above boxes represent the $n$.

775 Table 1. Sequences of primer pairs and FAM/TAMRA probes used in RT-qPCR reactions 776 for each of the target genes studied. $\beta$ tubulin was used as the reference gene.

777 Table 2. Fulton condition (K), hepatosomatic index (HSI), gonadosomatic index (GSI), liver, 778 gonad and body weight $(\mathrm{g})$, and fork length $(\mathrm{cm})$ (mean $\pm \mathrm{SD}, n=10$ ) and sex ratio 779 determined after $0,1,3$, and 6 months of exposure to different $\mathrm{BaP}$ treatments (acetone 780 control, low and high exposures).

781

782 Figure 1 


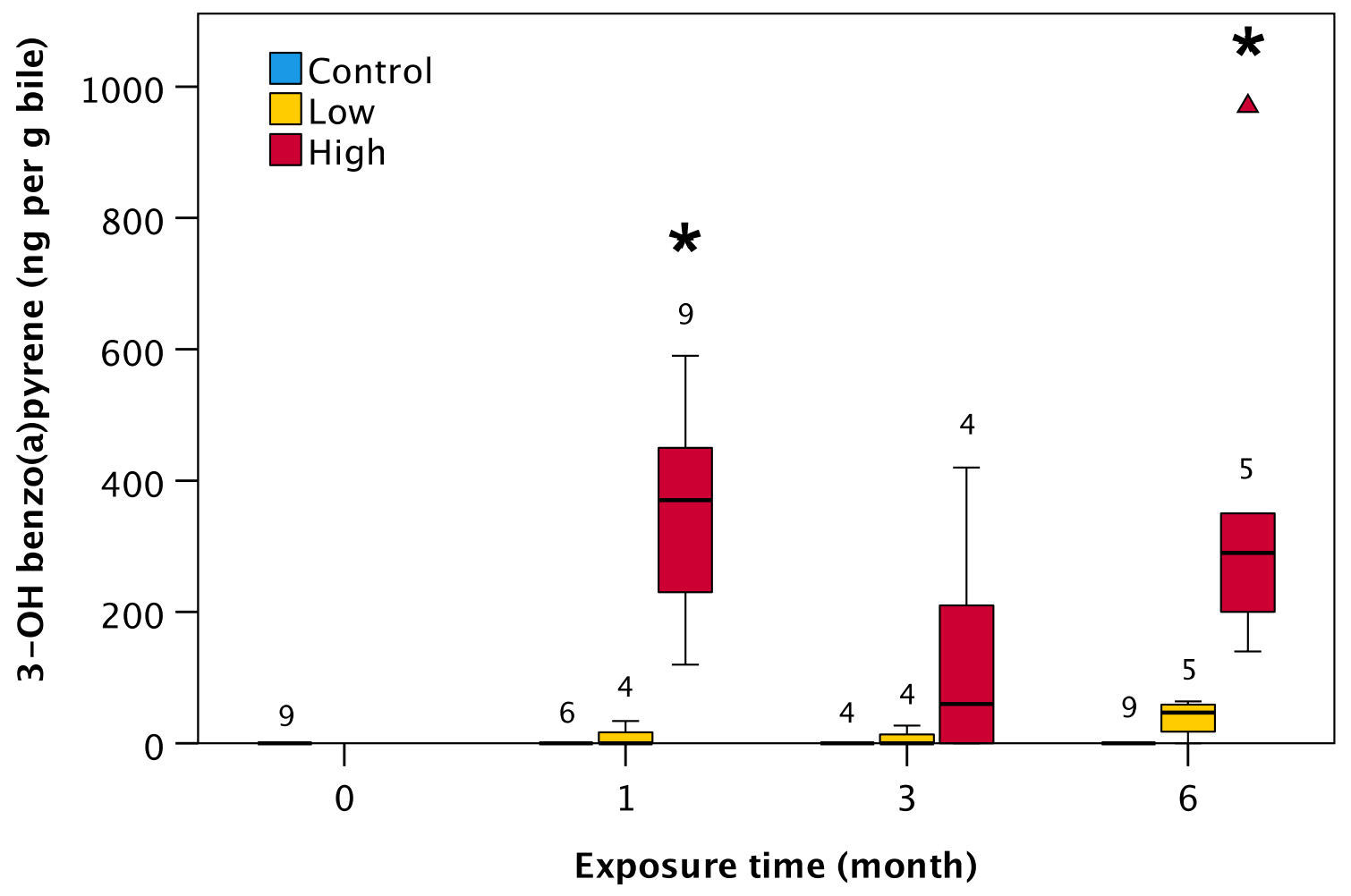

783

784

785

786

787

788

789

790

791

792

793 
Figure 2
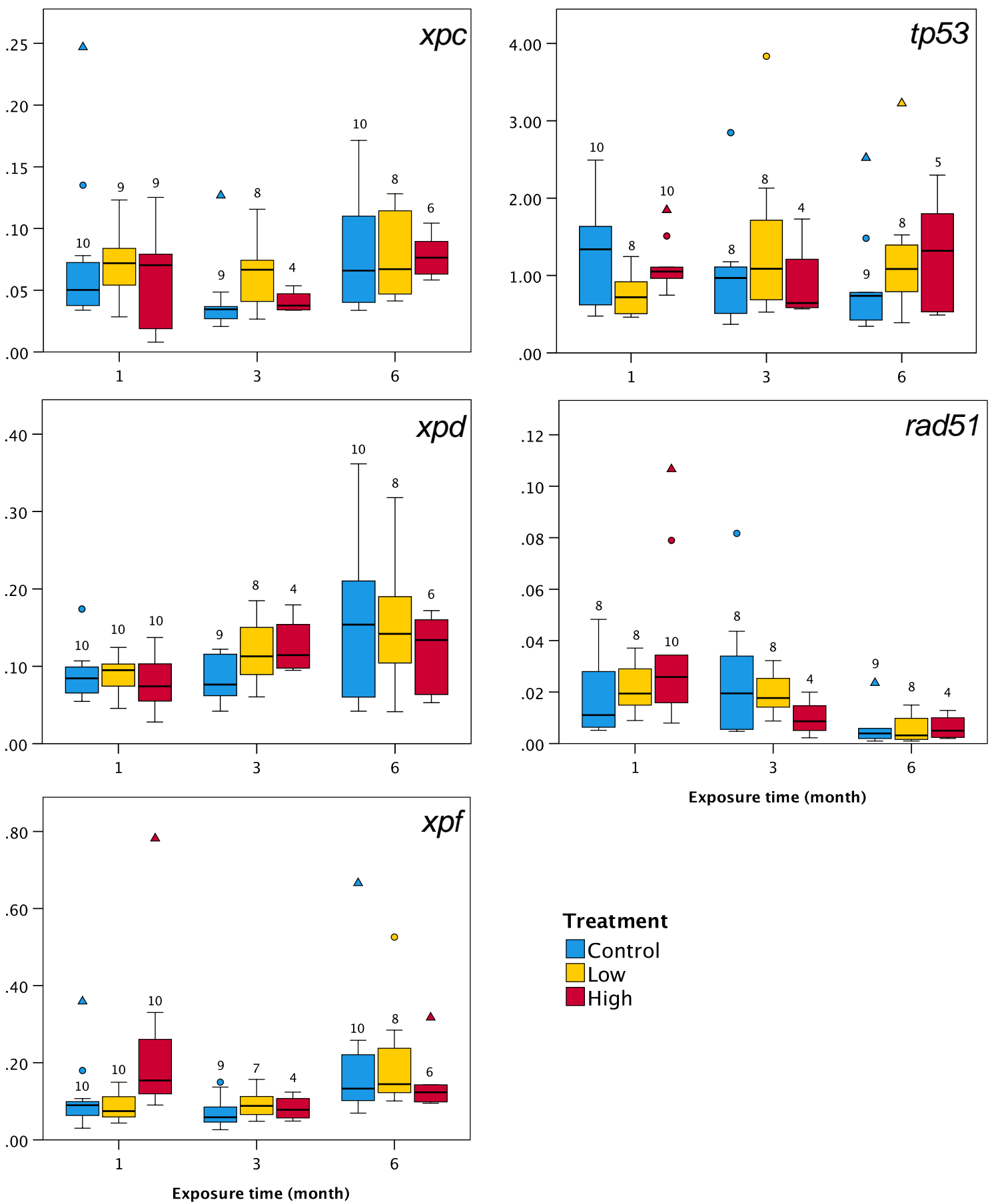

Treatment

$\square$ Control

$\square$ Low

High 
$801 \quad$ Figure 3
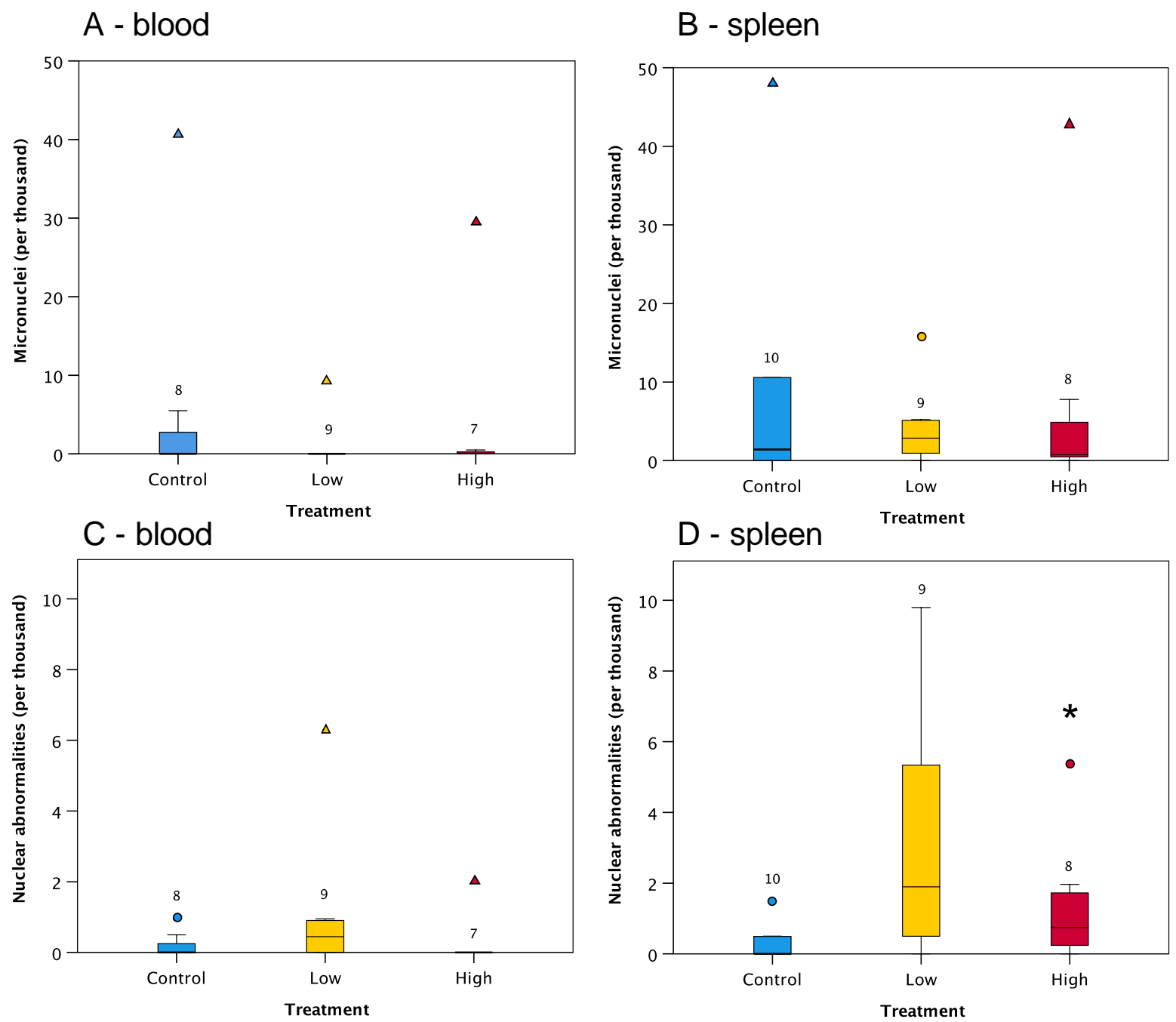

802

803

804

805 


\begin{tabular}{ll}
\hline Gene name & Primers and Probe Sequences 5'-3' \\
\hline$\beta$ tubulin & F: GCCCGGCACCATGGA \\
& R: TGGCCGAAACGAAGTGTC \\
& P: TCCGGTGCTTTCGGTCAGATCTTCA \\
$X P C$ & F: GCTTCGACTTCCATGGAGGAT \\
& R: CTTCGTGCTCCTCACACACAA \\
& P: CGCATGCTGTGACCGACGGCTAC \\
$X P D$ & F: TCATGTTCGGAGTCCCTTATGTT \\
& R: GGAACTGGTCCCGGAGTA \\
& P: ACACACAGAGCCGCATTCTGAAGGC \\
$X P F$ & F: ATCTGGACCTGGCGAGGAA \\
& R: TCCTGCTTTGCGGGTTT \\
& P: CTGGAGCCCGCCAACGCTACC \\
Rad51 & F: AAGAAGCCGATTGGAGGAAAC \\
& R: CGCCCCTCCTCAGGTACA \\
& P: TCATGGCCCACGCCTCCACC \\
tp53 & F: CCTCTGAGGGGCATGTTCTC \\
& R: GGGGCTCTTCTTTTTTGG \\
& P: TCCTGGGCGCGACCGCA
\end{tabular}

807

808

809

810

811

812

813

814

815

816

817

818 
819 Table 2

\begin{tabular}{cccccccccc}
\hline \multirow{2}{*}{ 0 month } & \multicolumn{3}{c}{1 month } & \multicolumn{3}{c}{3 months } & \multicolumn{3}{c}{6 months } \\
& Control & Low & High & Control & Low & High & Control Low & High \\
\hline
\end{tabular}

\begin{tabular}{|c|c|c|c|c|c|c|c|c|c|c|}
\hline Fork l. (cm) & $15.9 \pm 1.6$ & $16.4 \pm 1$ & $16.7 \pm 1.6$ & $16.9 \pm 1.7$ & $17.8 \pm 1.6$ & $16.8 \pm 1.9$ & $17.3 \pm 1.5$ & $16.4 \pm 1.5$ & $17.2 \pm 0.7$ & $17.3 \pm 1.2$ \\
\hline Total w. (g) & $25.6 \pm 7.1$ & $29.3 \pm 5.6$ & $32.4 \pm 8.8$ & $33.2 \pm 9.1$ & $38.3 \pm 11.6$ & $32.1 \pm 8.5$ & $35.6 \pm 10.4$ & $32.7 \pm 10$ & $37.3 \pm 4.5$ & $36.7 \pm 8$ \\
\hline $\mathbf{K}$ & $5.2 \pm 0.5$ & $5.2 \pm 0.4$ & $5.5 \pm 0.5$ & $5.4 \pm 0.3$ & $5.3 \pm 0.7$ & $5.4 \pm 0.5$ & $5.3 \pm 0.4$ & $5.2 \pm 0.7$ & $5.3 \pm 0.4$ & $5 \pm 0.4$ \\
\hline Liver w. (g) & $2 \pm 0.9$ & $2.2 \pm 0.7$ & $2.5 \pm 0.9$ & $2.6 \pm 0.7$ & $2.7 \pm 1.2$ & $2.3 \pm 0.6$ & $2.8 \pm 1$ & $2.7 \pm 0.9$ & $2.6 \pm 0.5$ & $3 \pm 0.9$ \\
\hline HSI & $9.6 \pm 3.3$ & $9.4 \pm 2.1$ & $9.4 \pm 2.1$ & $10.4 \pm 2.8$ & $8.6 \pm 2.6$ & $9.3 \pm 2.3$ & $9.8 \pm 2.1$ & $12 \pm 3.9$ & $9.5 \pm 2$ & $11.3 \pm 2.3$ \\
\hline Gonad w. (g) & $0.3 \pm 0.2$ & $0.5 \pm 0.2$ & $0.5 \pm 0.3$ & $0.5 \pm 0.3$ & $1.4 \pm 0.5$ & $1.1 \pm 0.6$ & $1.6 \pm 0.9$ & $4.2 \pm 2.3$ & $5.6 \pm 1.3$ & $5 \pm 1.8$ \\
\hline GSI & $1.5 \pm 0.7$ & $2 \pm 0.5$ & $2.2 \pm 1$ & $1.8 \pm 0.6$ & $4.6 \pm 1.2$ & $4.1 \pm 1.8$ & $5.6 \pm 2.3$ & $16.9 \pm 6.8$ & $20.8 \pm 3.9$ & $19.3 \pm 6.4$ \\
\hline Sex ratio & 40 & 60 & 30 & 50 & 50 & 40 & 30 & 50 & 22 & 50 \\
\hline
\end{tabular}

820

821 


\section{Supplementary material}

Figure S1. Putative coding sequences used to design the primers and probe for the 6 genes studied. The pink marks indicate the location of the introns in the DNA sequence. Primers were designed to overlap the introns whenever possible to check the specificity of the qPCR reactions.

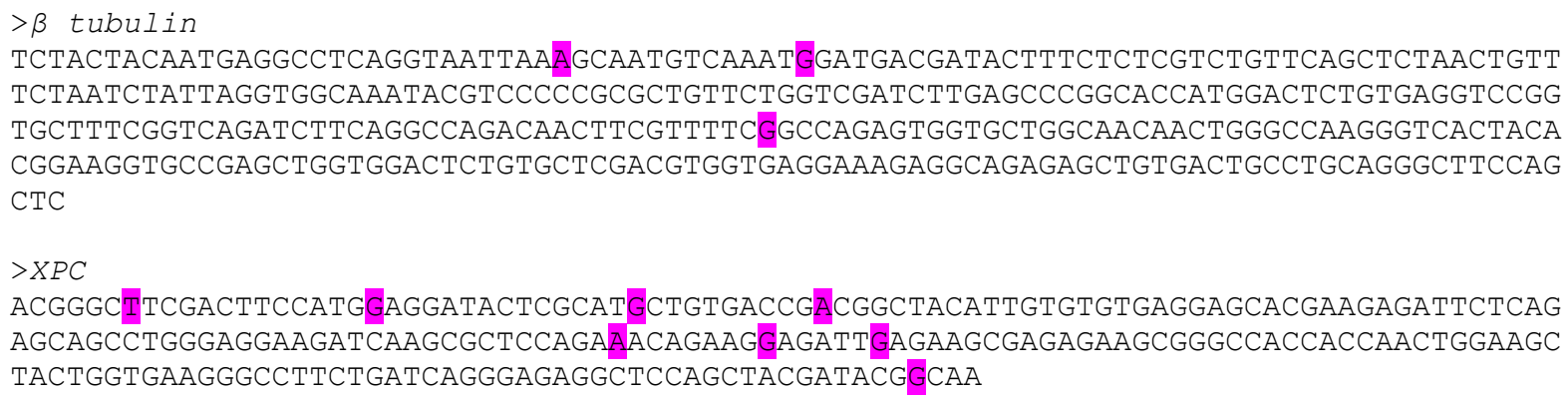
GCACCACTTTGGTCGGGCAGTGATCATGTTCGGAGTCCCTTATGTTTACACACAGAGCCGCATTCTGAAGGCGCGTCTGGAGT ACCTCCGGGACCAGTTCCAGATCCGGGAGAACGACTTCCTGACGTTCGACGCCATGCGCCATGCGGCCCAGTGCGTGGGCCGG GTCATCAGGGGCAAGACGGACTACGGACTCATGATCTTCGCTGACAAGCGCTACGCCCGGGCGGACAAGCGGGGGAAGCTGCC CCGCTGGATCCAGGAGCACATCAGCGACGGCAGCCTGAACCTCACGGTGGACGAGACGGTGCAGCTCTCCAAGCACTTCCTGA GGCAGATGGCCCAGCCCTTCAGACAGGAGGACCAGCTGGGTCTGTCACTGCTGACGATAGAACAGCTGGAGTCAGAGGAGATG CTGAAGAAGATCAGCCAAATGGCTCACCAGGCCTGACCACAT

\section{$>X P F$}

GATCTACAAGGCCAACCGCCCCGGGAAGACGCTGCGGGTGTATTTCCTGATCTATGGAGGATCCACAGAGGAACAGAAGTATC TCACCGCGCTCTCCAAGGAGAAGAAAGCCTTCGAACACCTCATCAGGGAGAAGGCGACCATGGTTGTGCCGGAGGAGCGAGAG GGTCGAGAAGACACCAATCTGGACCTGGCGAGGAATCTGGAGCCCGCCAACGCTACCACCAACACCCGCAAAGCAGGAGGCCA GGACCAGCCCAGGGAGCCCTCCCGGGTCATCGTGGACATGCGGGAGTTCCGCAGCGAGCTGCCCTCCCTGCTGCACCGCCGCG GGCTGGACATCGAGCCGGTCACCCTGGAGGTGGGCGACTACATCCTGACGGCGGACACCTGCGTGGAGCGCAAGAGCGTGAGC GACCTGATCGGCTCGCTGCAGAGCGGCCGCCTCTACACGCAGTGCGTGTCCATGACGCGCTACTACAAGCGGGCCGTGCTGCT CATCGAGTTCGACCCGGCCAAGCCCTTCTCGCTGGTGGCGCGCTCCGAGTTCCGCCACGAGCTGTCGGCCAACGACGTCACGT CCAAGCTGACGCTGCTCACCCTGCACTTCCCGCGCCTGCGCCTCCTCTGGTGCCCCTCGCCCCACGCCACGGCCGAGCTCTTC GAGGAGATGAAGCGGGGCCGCGGCGAGCCGGACGCCGCCGCCGCGCAGGCCATCGCGGCCGAGTCGGACGCCAGGACGACGGC GGAGCTGTACAACCCGGCGCCGTACGACTTCCTGCTGAAGATGCCGGGGGTCAACGCCAAGAACGTGCGGGCGCTGGTGAGCA AGGCGGACAGCCTGGCCGCGCTGGCCGAGTTCAGCCAGGAGAGGCTGGCGCAGGTCCTGGGGCACACCGGCAACGCCAAGATG CTCTACGAGTTCCTGCACAACGTGGCCGACGTGCCCGCGCCAGCTGCCAAGGGCAGACGGACGTGAAGGGAAAGACT

$>$ rad51

ATGGCTATGAGGAGTGAAGTGCGTTTGGAGGAGGAGGTAGAGGTGGAGGAGAACTTCGGCCCTCAGCCCATCAGTCGACTGGA GCAAAGCGGTGTGAGCAGCAGTGACCTGAAGAAGCTGGAGGAGGCGGGCTTCCACACCATCGAGGCCGTGGCCTACACCCCCA AGAAAGAGCTGCTCCACATCAAGGGCATCAGCGAGGCCAAGGCCGACAAGATCCTGGCGGAGGCAGCCAAGCTGGTGCCCATG GGCTTCACCACGGCAACGGAGTTCCACCAGCGGCGGGCGGAGATCATCCAGATCTCCACCGGCTCCAAGGAGCTGGACAAATT GTTAATGGGGGGAATGGAGACGGGTTCCATCACGGAGATGTTTGGAGAGTTCCGGACGGGGAAGACACAGCTGTGCCACACTC TGGCTGTCACCTGCCAGCTGCCCATCGACCAGGGCGGGGGAGAGGGCAAGGCCATGTACATCGACACCGAGGGAACCTTCCGG CCGGAGCGCCTGCTGGCCGTGGCCGAGAGGTACGGGCTGGTGGGCAGCGACGTCCTGGACAACGTGGCGTACGCCCGGGCCTT CAACACCGACCACCAGACCCAGCTGCTGTACCAGGCCTCCGCCATGATGGCAGAGTCACGCTATGCCCTGCTCATCGTGGACA GCGCCACCGCTCTGTACCGGACGGACTACTCCGGTCGGGGGGAGCTGTCGGCCCGGCAGGGCCACCTCGGCCGCTTCCTCCGC ATGCTGCTGCGGCTGGCCGACGAGTTTGGCGTTGCCGTGGTGATCACCAACCAGGTGGTGGCCCAGGTGGACGGGGCGGCCAT GTTCTCGGCCGACCCCAAGAAGCCGATTGGAGGAAACATCATGGCCCACGCCTCCACCACGCGGCTGTACCTGAGGAAGGGGC GGGGAGAGACCCGGATCTGTAAGATCTACGACTCCCCCTGCCTCCCGGAGTCGGAGGCCATGTTCGCCATCAACGCCGACGGC GTGGGCGACGCCAAGGACTGA 
$>p 53$

CGACGCTCCTTCTGAACTACATGTGCAACAGCTCCTGCATGGGAGGGATGAACCGGAGAGCCATCCTGACCATCCTGACCCTG GAGTCCTCTGAGGGGCATGTTCTCGGGCGGCGTTGCTTCGAGGTGCGCGTCTGTGCCTGTCCTGGGCGCGACCGCAAGACGGA GGAGGGCAACGTGGAGAAAAAGACGGAGGGATCCAAGCCCACCAAAAAAAAGAAAGAGCCCCCCCACTCCGGCCCCCACGGCT CCGCCCAAGAGGGTCCTGTCCGCCTCCAGCGCTGAAGAGGAGGATAAGGAGGTGTTTGTGCTACAGGTCGTTGGCCGGAAGAG ATTCGAGATCCTGAGGCAGATAAACGATGCACTCGCGCTGCAGGAGAGGATGACAGTCAAGCAGGAGGTCCAAGGAGGGCCGT CGCGGGGAAAGAGACGGCTGGGGGACCGGACAGACGAGGGGACCGACTGAGCGACCGTCCAACCGACCGTCCAACATAACACT GCCACAGCGAACCCCGTTATTTTCTACACTTTTCTTTTGTCATTCCTATTTTTATTTTTTTTCATAGCTTTTTTTTCAGCATA

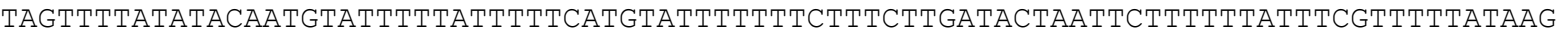
AGGCCATG

Figure S2. Basophilic foci of cellular alteration diagnosed in liver of a polar cod exposed to the low BaP concentration (magnification $\mathrm{x} 40$ ).

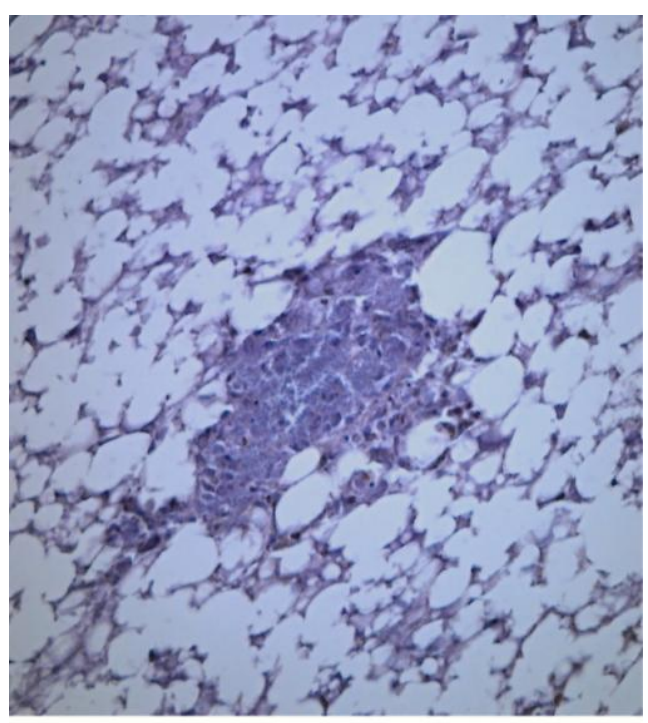

